\title{
The curative effects of shortwave diathermy on treating Novel coronavirus (COVID-19) pneumonia: A structured summary of a study protocol for a randomised controlled trial
}

\author{
Mohammad Nasb ${ }^{1,2+}$, Zulfiqar Ali Sayed Shah ${ }^{1 \dagger}$, Liangjiang Huang ${ }^{1,3}$, Qian $\mathrm{Li}^{1,3}$ and Hong Chen ${ }^{1,3^{*}}$ (D)
}

\begin{abstract}
Objectives: To evaluate the therapeutic effects of ultra-short-wave diathermy (SWD) on COVID-19 pneumonia. The hypothesis is that SWD may minimise pneumonic inflammation and shorten the duration of the time to positiveto-negative conversion of COVID-19 nucleic acid test.

Trial design: This is a single centre, 2-arm (1:1 ratio), evaluator blinded, parallel group design superiority randomised, controlled clinical trial.

Participants: The inclusion criteria were: (1) Age 18-65 years, (2) COVID-19 nucleic acid test is positive, (3) Lung CT showed multiple patchy ground glass shadows or other typical manifestations of both lungs. The exclusion criteria were: (1) Patients who need ICU management, (2) Positive tests for other pathogens such as Tuberculosis, Mycoplasma, (3) Patients with respiratory failure or requiring mechanical ventilation, (4) Patients with metal implants or pacemakers, (5) Those with shock (6) Those that have bleeding tendency or active bleeding in the lungs, (7) Patients with multiple organ failure who need ICU monitoring and treatment, (8) Cancer patients and those with severe underlying diseases, (9) Pregnant or lactating women, (10) Patients with severe cognitive impairment who cannot follow the instructions to complete the treatment, (11) Those without signed informed consent and (12) Those with other contraindications to short wave. This study will be conducted in Tongji Hospital, Caidian, Wuhan, People's Republic of China.
\end{abstract}

(Continued on next page)

* Correspondence: chenhong1129@hust.edu.cn; 1432133443@qq.com

${ }^{\dagger}$ Mohammad Nasb and Sayed Zulfiqar Ali Shah contributed equally to this work.

${ }^{1}$ Department of Rehabilitation Medicine, Tongji Hospital, Tongji Medical College, Huazhong University of Science and Technology, Wuhan 430030, People's Republic of China

${ }^{3} \mathrm{WHO}$ Collaborating Centre for Training and Research in Rehabilitation,

Tongji Hospital, Tongji Medical College, Huazhong University of Science and Technology, Wuhan 430030, People's Republic of China

Full list of author information is available at the end of the article

C The Author(s). 2020 Open Access This article is licensed under a Creative Commons Attribution 4.0 International License, which permits use, sharing, adaptation, distribution and reproduction in any medium or format, as long as you give appropriate credit to the original author(s) and the source, provide a link to the Creative Commons licence, and indicate if changes were made. The images or other third party material in this article are included in the article's Creative Commons licence, unless indicated otherwise in a credit line to the material. If material is not included in the article's Creative Commons licence and your intended use is not permitted by statutory regulation or exceeds the permitted use, you will need to obtain permission directly from the copyright holder. To view a copy of this licence, visit http://creativecommons.org/licenses/by/4.0/. The Creative Commons Public Domain Dedication waiver (http://creativecommons.org/publicdomain/zero/1.0/) applies to the data made available in this article, unless otherwise stated in a credit line to the data. 
(Continued from previous page)

Intervention and comparator: The experimental group will be given the nationally recommended standard medical treatment + ultra-short-wave diathermy treatment. Ultra-short-wave therapy treatment will be performed through application of ultra-short-wave therapy machine electrodes on the anterior and posterior parts of the trunk for 10 minutes, twice a day for 12 consecutive days. The comparator will be the control, not receiving ultra-short-wave therapy, and will be given only the nationally recommended standard medical treatment.

Main outcomes: The primary outcome measures will be time to positive-to-negative conversion of COVID-19 nucleic acid test by pharyngeal swab, in days assessed at $7^{\text {th }}, 14^{\text {th }}, 21^{\text {st }}$ and $28^{\text {th }}$ days. The secondary outcome measures include nucleic acid test rate and recovery from symptoms, Vital signs assessment, Computed Tomography, Complete blood count, serum analysis and SIRS scale scores. Blinded evaluation will be at baseline (the day of starting ultra-short-wave diathermy) and after 28 days following the interventions.

Randomisation: A Randomization plan will be generated online on www.randomization.com using permuted blocks method, by a statistician who will not be part of the study. Small blocks of various sizes will be used. Patients will be randomized (1:1) between the experimental and control groups

Blinding (masking): This will be an evaluator blinded study. Due to the nature of the intervention, blinding of patients and healthcare workers is not possible.

Numbers to be randomised (sample size): A total of 410 patients will be randomised in 1:1 ratio to two groups: experimental group $(\mathrm{n}=205)$ and control group $(\mathrm{n}=205)$.

Trial Status: Protocol version 1 was approved on 02/12/2020. Recruitment for this trial began on 02/18/2020 and will be ongoing till the required sample size is reached. The analysis deadline is August 2020.

Trial registration: This randomised controlled trial has been prospectively registered with the Chinese Clinical Trials (ChiCTR2000029972) on 17 February 2020.

Full protocol: The full protocol is attached as an additional file, accessible from the Trials website (Additional file 1). In the interest in expediting dissemination of this material, the familiar formatting has been eliminated; this Letter serves as a summary of the key elements of the full protocol."

The study protocol has been reported in accordance with the Standard Protocol Items: Recommendations for Clinical Interventional Trials (SPIRIT) guidelines (Additional file 2).

Keywords: COVID-19, Randomised controlled trial, Protocol, Coronavirus, Ultra short-wave diathermy, Pneumonia

\section{Supplementary information}

Supplementary information accompanies this paper at https://doi.org/10. 1186/s13063-020-04534-5.

Additional file 1. Full Study Protocol.

Additional file 2. SPIRIT 2013 Checklist: Recommended items to address in a clinical trial protocol and related documents.

\section{Acknowledgements}

We are thankful to all Tongji Hospital staff where the trial will take place.

\section{Authors' contributions}

Authors MN and SZAS equally contributed to designing, writing, formatting of this study. Author LH and LQ contributed in drafting of the final manuscript and will assist in data collection for the trial. Author HC contributed to conception, designing and supervision of the study. All authors have read and approved the manuscript.

\section{Funding}

The National Natural Science Foundation, an external peer-review took place during the funding process. The funder had no role in the design and conduct of the study; collection, management, analysis, and interpretation of the data; preparation, review, or approval of the manuscript; and decision to submit the manuscript for publication.

\section{Availability of data and materials}

The data set will be made available upon reasonable request to the corresponding author after completion of the study.

\section{Ethics approval and consent to participate}

This study is approved by the Ethics Committee of Tongji Hospital of Tongji Medical College of Huazhong University of Science and Technology (IRB ID: TJ-C20200127) on 02/12/2020. We declare that the ethical approval for this study has been obtained from an appropriate ethical approval committee mentioned above. The study will be explained to all eligible patients and a written informed consent will be obtained from all patients for participation in this study.

\section{Consent for publication}

Not applicable.

\section{Competing interests}

The authors declare that they have no competing interests.

\section{Author details}

${ }^{1}$ Department of Rehabilitation Medicine, Tongji Hospital, Tongji Medical College, Huazhong University of Science and Technology, Wuhan 430030, People's Republic of China. ${ }^{2}$ Department of Physical Therapy, Health Science 
Faculty, Albaath University, Homs, Syria. ${ }^{3}$ WHO Collaborating Centre for Training and Research in Rehabilitation, Tongji Hospital, Tongji Medical College, Huazhong University of Science and Technology, Wuhan 430030, People's Republic of China.

Received: 16 June 2020 Accepted: 18 June 2020

Published online: 03 July 2020

\section{Publisher's Note}

Springer Nature remains neutral with regard to jurisdictional claims in published maps and institutional affiliations.

Ready to submit your research? Choose BMC and benefit from:

- fast, convenient online submission

- thorough peer review by experienced researchers in your field

- rapid publication on acceptance

- support for research data, including large and complex data types

- gold Open Access which fosters wider collaboration and increased citations

- maximum visibility for your research: over $100 \mathrm{M}$ website views per year

At $B M C$, research is always in progress. 